\title{
The Effects of Soluble Salts at the Metal/Paint Interface: Advances in Knowledge
}

\author{
D. de la Fuente, B. Chico, M. Morcillo* \\ National Centre for Metallurgical Research (CENIM-CSIC) \\ Avda. Gregorio del Amo 8, 28040-Madrid, Spain
}

Received 29 September 2005

\begin{abstract}
The presence of soluble salts (particularly sulphates and chlorides) at the metal/paint interface is known to have a detrimental effect on the integrity of most paint systems. Though this is a long-standing problem, it has recently come to receive greater attention from the protective coatings industry. International Standards Organization (ISO) has for some time been trying to develop a standard about guidance levels for water-soluble salt contamination before the application of paints and related products.

In the paper the following points are reviewed: degradation mechanisms, nature and sources of soluble salts, their distribution on the metallic surface, the joint action of chlorides and sulphates, the effect of the joint presence of rust, new methodologies for sample preparation with known levels of soluble salts, measuring soluble salts, establishment of threshold levels, removal of salts and new suitable coating systems for applying on substrates contaminated with soluble salts.
\end{abstract}

Keywords: protective coatings in corrosion, metal/paint interface, paint degradation, sulfates and chlorides in corrosion, ISO standards.

\section{Introduction}

The presence of hydrosoluble species (mainly chlorides and sulphates) at the metal/paint interface promotes osmotic blistering of the coating and underfilm metallic corrosion. Both processes can lead to the deterioration of the paint system in a very short period of time. Loss of adhesion, cathodic disbondment and scribe creep can be also consequences of the presence of soluble salts [1]. It was Mayne [2] who first reported in 1959, that when the soluble salt concentration in the rust layer at the steel/paint interface exceeded a certain threshold value it was common to observe premature deterioration of the paint

\footnotetext{
*Corresponding author. E-mail address: director@cenim.csic.es
} 
coating. This usually took the form of fine blistering of the paint film and an increase in the corrosion rate of the metallic substrate under the coating.

Though the topic lay dormant for some time, interest in studying this important phenomenon has grown over the last 20 years [3] to the point that much of the protective coatings industry currently requires testing soluble salts (e.g., chlorides and sulphates), and trends show these requirements are increasing. Numerous corrosion and coating authorities have observed and reported on early failures and reduced lifetime of coatings applied over steel contaminated by soluble salts. International Standard Organization (ISO) has for some time been trying to develop a standard about guidance levels for water-soluble salt contamination before the application of paints and related products. Since the different industrial sectors affected by the issue of soluble salts became aware of this problem (paint manufacturers and applicators, surface preparation and cleaning companies, metallic structures maintainers, etc.) many studies have been developed on this topic.

Morcillo [1] in 1999 publishes in Progress in Organic Coatings a review paper of the subject, making reference especially to the related research that had been carried out by him and his co-workers over the previous 15 years. Since then some advances have been get on this topic.

In this paper special emphasis will be focused on the following aspects: a) degradation mechanisms, b) nature and sources of soluble salts, c) its distribution on the metallic surface, d) the joint action of chloride and sulphates, e) the effect of the joint presence of rust and new methodologies for sample preparation with known levels of soluble salts, f) measuring soluble salts, g) establishment of threshold levels, h) removal of salts and i) new suitable coating systems for applying on substrates contaminated with soluble salts.

\section{Degradation mechanisms}

As it has been mentioned above, due to the presence of soluble salts at the metal/paint interface, osmotic blistering of the coating and underfilm metallic corrosion can lead to the deterioration of the paint system in a very short period of time.

\section{Osmotic blistering}

A coating behaves as an impermeable membrane; thus, allowing moisture but not salts to penetrate $[4,5]$. When a paint coating is applied on a metallic surface or paint layer contaminated with soluble salts, an osmotic blistering process takes place (Fig. 1). The blisters are first filled with water and later with corrosion products from the corrosion of the metallic substrate. This indicates that osmosis is the mechanism of blister formation. Subsequently blistering seems to reach a steady state where little or no further blistering occurs [6]. 


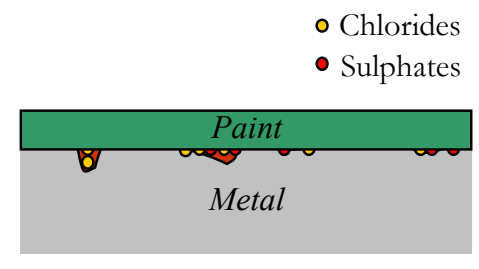

(a)

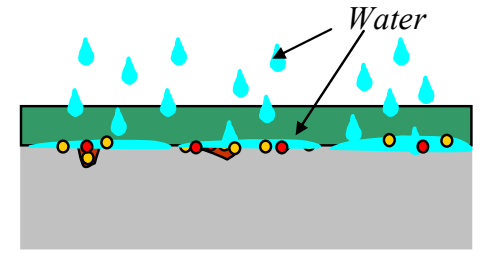

(b)

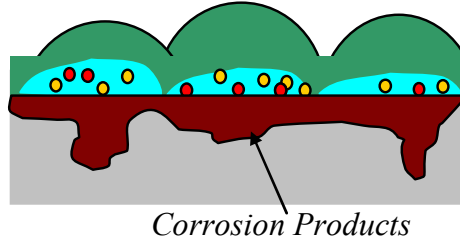

(c)

Figure 1. Osmotic blistering of the paint coating and underfilm corrosion of the metal substrate induced by the presence of soluble salts at the metal/paint interface.

Once the painted surface has been wetted and water has permeated through the paint coating (Fig 1b), the osmotic force generated by the difference in the concentration of the solutions on either side of the film will promote the diffusion of water through the semipermeable paint layer from the more dilute solution (paint surface) to the more concentrated solution (salt dissolved at the metal/paint interface or between the paint layers). The process will continue for as long as there is a difference between the concentration of the two solutions. As the soluble substance dissolves under the paint layer, the pressure caused by the increase in volume can exert a greater force than the paint adhesion and cohesion forces, giving rise to the formation of a blister (Fig. 1c). It is believed that blisters do not form in one single step but in several successive steps of growth and release of pressure due to the viscoelastic and deformation response of paint coatings [7].

\section{Underfilm corrosion}

The presence of FeSO4, as water soluble contaminant in the corrosion products layer, promotes an accelerated rust formation, which very quickly leads to blistering and the destruction of the coating.

Fig. 2 shows the cyclic process of rusting as caused by ferrous sulphate [8]. Similar processes could operate in the case of other ions $[9,10]$

In a search for details about the underfilm corrosion mechanism, a study was conducted by Morcillo et al. [11]. The absence of corrosion for uncontaminated interfaces suggested that the controlling factor of the underfilm corrosion process on contaminated surfaces was the ionic conduction resulting from the saline deposit at the interface; low contaminant concentrations were enough to promote significant underfilm corrosion of steel after very few hours of testing. In the case of highly contaminated surfaces, ionic conduction was no longer the controlling factor of underfilm corrosion, which was then governed by the diffusion of oxygen through the varnish film. 


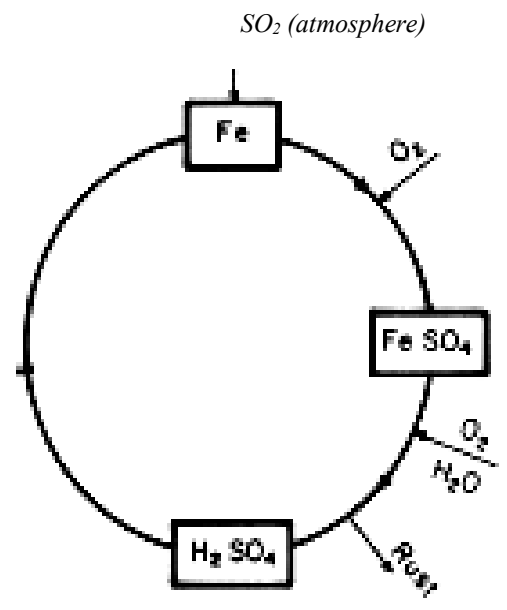

Figure 2. Cyclic mechanism of rust formation caused by the presence of ferrous sulphate.

\section{Nature and sources of soluble salts}

There are numerous sources that cause the existence soluble salts over metallic surfaces. Let us cite the most important:

1. Atmospheric pollution causes the presence of soluble salts within the corrosion products layer. The most common atmospheric contaminants, $\mathrm{SO}_{2}$ (anthropogenic contaminant in urban and industrial zones), and marine chlorides (natural contaminant in coastal environments), are those which have received greatest attention.

2. Chlorides are deposited on bridges and vehicles as a result of de-icing salts applied on roads in the winter [12].

3. Contamination in sandblasting operations through the use of contaminated abrasives: chlorides, sulphates, fluorides, etc., either in first use or recycled.

The most common interface contamination, and that to which greatest research effort has been dedicated is that corresponding to sodium chloride $(\mathrm{NaCl})$ and iron sulphate $\left(\mathrm{FeSO}_{4}\right)$. Very little research work has been carried out in relation with other saline contaminants $[13,14]$.

\section{Its distribution on the metallic surface}

Salt contaminants tend to be located at the metal/corrosion products interface and at the bottoms of pits, making it difficult to eliminate them by the techniques normally used for the preparation of steel surfaces. This has been confirmed in many studies by other authors, including a study carried out in our laboratory with specimens exposed for one year in 39 testing stations distributed across 14 Ibero-American countries [15]. In this study it was seen that practically all of the chlorides and sulphates present were concentrated in the adherent stratum of the rust layer.

The identification and quantification of saline contaminants among the atmospheric corrosion products of steel has been the subject of some research. 
On a literature survey on this matter, Flores and Morcillo [15] draw two conclusions: (i) the concentration of saline contaminants in rust is seemingly also related to the season in which the steel is exposed and then withdrawn from the aggressive atmosphere, i.e., it is subject to a seasonal effect $[2,16,17]$. This is specially the case with sulphates, which move to the outer rust layer in periods where sulphate nests are scarcely active [18] and can thus be readily leached by rainwater, with their concentration decreasing considerably as a result. On the other hand, the washing action of rainwater on chlorides, which tend to accumulate at the steel/rust interface, is less important, and (ii) the presence of saline contaminants in rust is closely related to the type of atmosphere to which the steel is previously exposed $[16,17,19,20]$.

\section{The joint action of chlorides and sulphates}

It is interesting to ascertain the effect produced by the joint action of the two contaminants, since this circumstance often occurs in practice (e.g., industrial zones near the coast). In a research carried out by the author on this topic [11], for a determined level of one of the contaminants, the incorporation of the second contaminant promotes an increase in the corrosion of the underfilm steel, suggesting a quasi-additive effect.

\section{The effect of the joint presence of rust and new methodologies for sample preparation with known levels of soluble salts}

In the first studies carried out in relation with this issue in the early 1960's $[2,21,22]$, it was already noted that soluble salts tend to accumulate in the innermost layers of the corrosion products, precisely those which are most firmly adhered to the metallic substrate. They are also frequently found inside pits.

However in most laboratory studies carried out to obtain metallic substrates contaminated with soluble salts, mainly for the establishment of critical level, the specimens are usually prepared by dosing the saline contaminant in a uniform or homogeneous way on the clean substrate. The result, in terms of salts distribution, is considerably different to that found in practice. Thus there was a need to develop new laboratory methods in order to obtain specimens contaminated with known levels of soluble salts, achieving an intermediate condition between natural contamination and artificial contamination by dosing. In this way it would be possible to overcome the disadvantages of natural exposure (long waiting time in specimen preparation, unknown levels obtained after the exposure and embedded into the corrosion products, associated costs, etc.) while obtaining a more similar salts distribution to that found in practice.

In this way, in order to more closely approximate the situation occurring in practice, the following experiment was performed in the laboratory [23]. Coldrolled pre-weighed steel specimens were exposed to wet-dry cycles (using distilled water sprays), building up a rust layer of approximately $1 \mathrm{~g} / \mathrm{cm}^{2}$. After a light brushing to remove the not firmly adhered rust, variable amounts of $\mathrm{NaCl}$ and $\mathrm{FeSO}_{4}$ solutions were added. The samples were then coated with a clear 
coating of alkyd-melamine to a dry film thickness of $30 \mu \mathrm{m}$. The main results obtained were as follows:

(i) The significant corrosion of uncontaminated rusted specimens, which contrasts with the absence of corrosion in uncontaminated and nonrusted specimens. The rust in that case supplies the cathodic reaction of the corrosion process underneath the paint film, as has been postulated by some other researchers [44].

$$
\begin{gathered}
2 \mathrm{FeOOH}+2 \mathrm{H}^{+}+2 \mathrm{e}^{-} \rightarrow 2 \mathrm{Fe}(\mathrm{OH})_{2} \\
2 \mathrm{FeOOH}+\mathrm{Fe}^{2+} \rightarrow 2 \mathrm{Fe}_{3} \mathrm{O}_{4}+2 \mathrm{H}^{+}
\end{gathered}
$$

In this case the corrosion rate does not depend on the rate of oxygen transport through the rust film since the oxidizing agent is in the rust itself.

(ii) The corrosion of steel is dependent on the nature of saline contamination at the interface.

(iii) No great dependence can be deduced on the presence of rust at the contaminated interface.

In a second attempt to more closely approximate the situation occurring in practice, it was tried to reproduce in the laboratory the atmospheric corrosion process of steel in environments contaminated with $\mathrm{Cl}^{-}$and $\mathrm{SO}_{2}$ using two of the most common climate cabinets for accelerated corrosion tests, the salt-fog cabinet for the case of chlorides and the Kesternich cabinet for the case of sulphates. The obtained results show that this new methodology allows the preparation of steel substrates contaminated with preestablished chloride and/or sulphate levels [24,25]. The comparative analysis performed with the different surface characterisation techniques (SEM, EDX, X-Ray Mapping and XPS) and with the Kelvin Probe electrochemical technique (SKP) allows it to be stated that salt distribution obtained with the cabinets contamination method more faithfully reflects that which occurs in natural exposure in the atmosphere than the distribution habitually obtained with the conventional homogeneous dosing method [26,27].

On the other hand, Mitschke [28] points out that the homogeneous method could be a more acceptable method for applying salt contamination because it gives a slightly more conservative evaluation of performance, is easier to prepare, and has a more uniform distribution of chloride over the panel. The homogeneous method could be the best method for the establishment of the most conservative critical levels. However, the establishment of conservative critical levels could involve unnecessary costs. 


\section{Measuring soluble salts}

Much of the industry now requires testing for soluble salts, and trends show that these requirements are increasing. Therefore, several field methods for extracting soluble from surfaces to be painted have been developed. The most prominent are swabbing and different adhesive patches. Most of them are described in SSPC-TU-4 [29], "Field Methods for Retrieval and Analysis of Soluble Salts on Substrates". Unfortunately, the efficiency of extraction varies quite significant among these methods and within a given method.

In 1991 the Federal Highway Administration (FHWA) completed a contract research study entitled "Effect of Surface Contaminants on Coating Life" [30]. In it, numerous available chloride test methods, were investigated and compared. It was noted that extraction efficiency depends on many factors: extraction time, steel surface condition (roughness, degree of rusting, etc.), salt concentration on the steel surface, etc. However, an extraction efficiency of $15-35 \%$ for the swabbing method and of $40-60 \%$ in the case of the different extraction cells could be defined. Thus, if one swabs, multiplying the values for surface contamination by 4 (reflecting a nominal 25\% recovery) is recommended. For values derived from cell recovery, multiplying by a factor of 2 is recommended.

Previous and other studies (i.e., Flores et al. [31]) have also concluded that in general the extractive efficiency of most field techniques is sufficient for the analysis of non-rusted steel surfaces, for instance to determine whether an abrasive used in a surface cleaning procedure has contaminated the surface or to detect any residual saline contaminant content after exhaustive cleaning. In these cases the extractive efficiency is around 90-100\% [32,33]. However, in the case of rusted surfaces the extractive efficiency decreases substantially, both on surfaces where the rust has been artificially generated in the laboratory [32,33] and on surfaces naturally rusted in the atmosphere [31]. The reason for this decrease is that the presence of rust impedes the access of water or extractive solutions to the innermost rust layers, where the salts frequently accumulate, and the subsequent recovery of the extract. Furthermore, the progressive rusting of the substrate increases the interaction between ions and the metallic substrate, which causes the ions to migrate to the bottom of pits, etc., hindering the extraction process; in other words the more rusted the surface, the more difficult it is to extract the soluble salts [30].

Much of the industry now requires better testing for soluble salts, and trends show that these requirements are increasing. Subsequently, new chloride test kits and improvements of the old kits have been developed.

In 2003, S. Ling-Chong et al. [33] evaluated three currently popular commercial chloride tests kits. These tests are the swab test, patch test and sleeve test; their detectors are ion detection strip, bottle titration liquids, and ion detection tube, respectively. The main disadvantage of each method is the liquid loss in the case of the swab method, that only minimum and maximum values are given (the actual values are not known) in the case of the patch extraction and detection kit and the bad recovery at low concentrations due to the poor sensitivity and unclear colour separation at the low reading end of the ion detection tube in the case of the sleeve test. Anyway, all methods tested provided, generally, a high chloride 
recovery on freshly doped panels. When chloride-contamination steel panels were aged at $37{ }^{\circ} \mathrm{C}$ and $57 \% \mathrm{RH}$ for 4 hours, the extraction recovery differed only slightly from that for freshly doped panels, and recoveries are all close to $100 \%$. However, when humidity reaches $78 \% \mathrm{RH}$ at $37{ }^{\circ} \mathrm{C}$, the extraction efficiency decreased significantly.

Thus there is still a clear need, on the part of the industrial sectors involved in the issue of industrial painting, to develop new extraction methods with field applicability that improve the extractive efficiency in the case of rusted surfaces, compared with the methods currently available.

An intent to improve the extraction efficiency of soluble salts on rusty steel has been made in our laboratories and a new extraction method has been developed [34]. In order to improve the extractive efficiency, use is made of two of the factors that affect the solubility of the salts, namely the temperature and stirring. Fig. 3 presents a complete scheme of the new extraction device developed. The device consists essentially of a cell, which is seated on the surface to be studied by means of an elastic washer and held fast by manual or automatic pressure, an auxiliary thermostatised closed deposit where the solvent (normally distilled water) is initially introduced, and a pump which injects the solution at high pressure into the cell, projecting it against the surface to be studied. The solution is then pumped back to the deposit from where it is once again recirculated.

1. Surface to be analysed.

2. Cell.

3. Plug.

4. Tubing to project the leaching liquid.

5. Tubing to collect the solution.

6. Support rim.

7. Elastic toric seal.

8. Elastic toric seal to avoid losses of solution.

9. Diffuser to spread out the jet.

10. Venting orifice.

12. Flexible input tube.

13. Flexible outlet tube.

14. Impulsion pump.

15. Suction pump.

16. Flexible tubing.

17. Flexible tubing.

18. Auxiliary deposit input tubing.

19. Auxiliary deposit outlet tubing.

20. Venting orifice.

21. Sealing plug.

22. Thermostabilised vessel.

23. Auxiliary deposit.

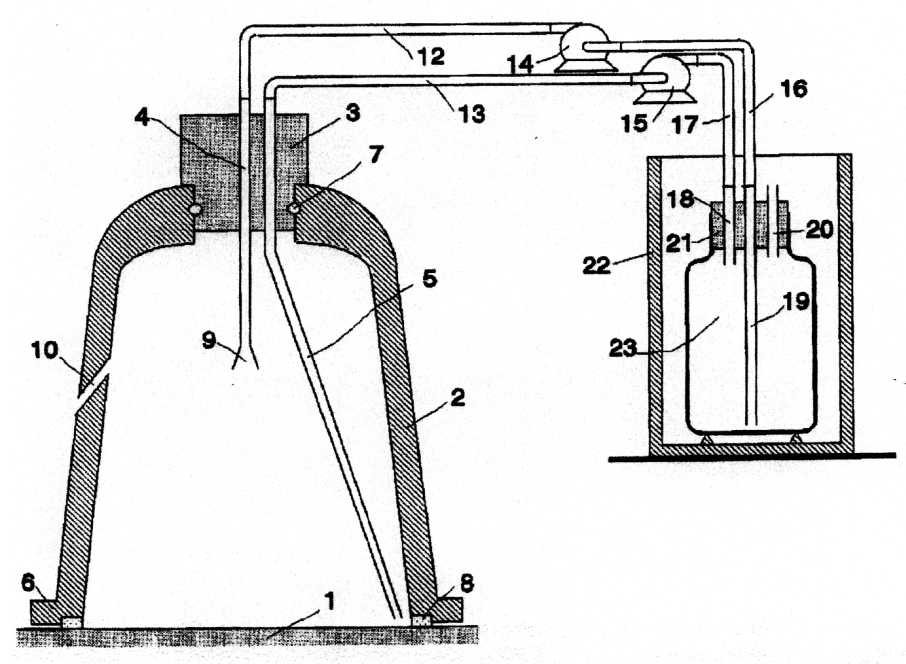

Figure 3. Scheme of the new proposed extraction method.

The results of a comparative study with other commercial extraction cells, performed on rusted steel surfaces obtained both by natural exposure in the 
atmosphere and artificially in climate cabinets, show that the new extraction method positively affect the soluble salt extraction efficiency [35,36]. The proposed new field extraction method has proven to be more effective in the extraction of soluble salts than the best of the commercially available methods considered, especially when the steel surface is rusted (Table 1).

Table 1. Comparative summary of extractive efficiency of the proposed new extraction method versus surface washing and sleeve-type cell.

\begin{tabular}{cccccc}
\hline & \multicolumn{2}{c}{$\begin{array}{c}\text { Extraction efficiency compared with reference } \\
\text { method (Boiling method was considered 100\%) }\end{array}$} & \multicolumn{2}{c}{$\begin{array}{c}\text { Difference compared with the } \\
\text { new extraction method }\end{array}$} \\
\cline { 2 - 6 } & New method & Swabbing & Sleeve-type cell & Swabbing & $\begin{array}{c}\text { Sleeve-type } \\
\text { cell }\end{array}$ \\
\hline $\begin{array}{c}\text { Total chlorides (rusted } \\
\text { surfaces) }\end{array}$ & $64 \%$ & $34 \%$ & $10 \%$ & $-30 \%$ & $-54 \%$ \\
$\begin{array}{c}\text { Residual chlorides } \\
\text { (after blast cleaning) }\end{array}$ & $68 \%$ & $54 \%$ & $19 \%$ & $-14 \%$ & $-49 \%$ \\
$\begin{array}{c}\text { Total sulphates } \\
\text { (rusted surfaces) }\end{array}$ & $41 \%$ & $21 \%$ & - & $-20 \%$ & - \\
$\begin{array}{c}\text { Residual sulphates } \\
\text { (after blast cleaning) }\end{array}$ & $66 \%$ & $49 \%$ & - & $-17 \%$ & - \\
\hline
\end{tabular}

With regard to the analysis of the extract, it has been seen that the best procedure is to perform a specific analysis for each of the ions present. Measurement of the conductivity of the extract, and subsequent transformation into chloride content, may give rise to considerable errors $(>500 \%)$, especially when the saline contamination is high, and due to ions other than the $\mathrm{Cl}^{-}$ion, such as sulphates.

\section{Establishment of threshold levels of soluble salts}

It has been observed that it seems to exist a critical or threshold value of salt contamination at the interface above which the stability of the paint coating is significantly affected, and below which the contamination level seems no danger for the coated system or has only a very low impact on the stability of the coating.

From currently available data, it is not possible to determine a definitive upper limit of soluble salt contaminants. Some authors have reported adverse effects due to chloride contamination as low as $5 \mathrm{mg} / \mathrm{m}^{2}$ whereas others have seen no detrimental effects with up to $1270 \mathrm{mg} / \mathrm{m}^{2}$. Different methods of doping the surface coupled with a variety of accelerated testing techniques have been used by the previous investigators making the comparison of results difficult [37]. The types of services (atmosphere, water immersion, etc.) also vary. So, it is difficult to set acceptable levels since each type of coating, film thickness, fillers, pigments, etc., also varies in susceptibility to soluble salt degradation. It is clear that different coating systems can tolerate different level of residual salt and the 
maximum tolerable salt level for specific coating systems varied depending on the exposure conditions. The US Navy [38] suggested a chloride limit of 30-50 $\mathrm{mg} / \mathrm{m}^{2}$, and this is in close agreement with previous German [39] and Swedish [40] proposals.

Though no specific limits have been established by industry for soluble salts, some guidance levels are emerging. Draft ISO 15235 [41] standard proposes 10$20 \mathrm{mg} / \mathrm{m}^{2}$ for atmospheric services. However, in a recent study in the framework of a ECSC project [42], it was found that the proposed maximum levels in the draft ISO standard are much lower than the levels established in this study for all the coating systems tested $\left(>150 \mathrm{mg} / \mathrm{m}^{2}\right.$, even $400 \mathrm{mg} / \mathrm{m}^{2}$ in the case of a zinc rich three layer system). These higher levels obtained agree available literature data obtained experimentally in many previous studies. Alblas and van Londen [3] in 1997, recently completed by de la Fuente [35], summarised the findings in the literature with respect to the threshold chloride levels (Fig. 4). As can be seen most of the studies establish a maximum allowable chloride level of 20-100 $\mathrm{mg} / \mathrm{m}^{2}$.

\section{Removal of salts}

Traditionally, the most effective method to prepare steel for the application of a coating is dry abrasive blasting. Dry blasting is most suitable for mechanically breaking up layers of rust, mill scale and coatings, and for eroding the steel to produce a profile, but it is not effective to remove all water-soluble salts. Usually neither the blasting nor much less the brushing of a metallic surface ensures the removal of all the soluble salts present. In order to adequately remove salts from the surface, it is often necessary not only to remove the corrosion products, but also to flush the salt from within the corrosion pits. For this reason, the use of some form of water in the surface preparation method is desirable.

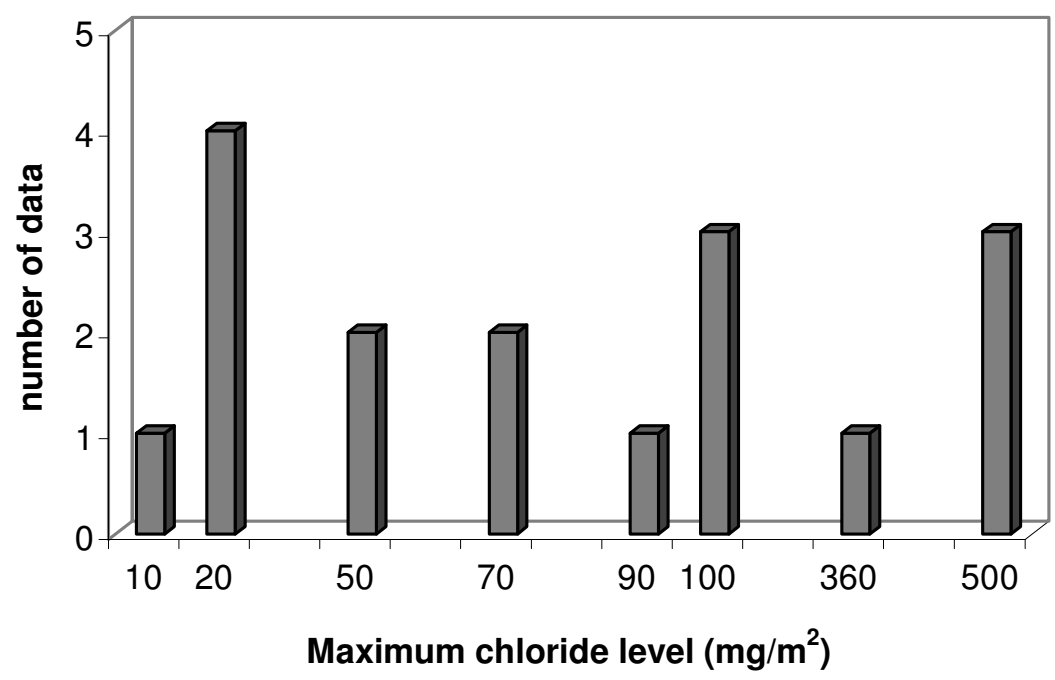

Figure 4. Graphical presentation of the maximum allowable chloride concentrations from experimental studies. 
Hydroblasting is a surface cleaning technique that relies entirely on the energy of water striking a surface to achieve a cleaning effect. Abrasives are not frequently used in hydroblasting systems. Consequently the problems caused by dust pollution and by the disposal of spent abrasives are eliminated. Two different hydroblasting operating pressures are commonly encountered: a) high pressure hydroblasting, operating at pressures above 680 bar, and b) ultra high pressure hydroblasting, operating at pressures above 1700 bar.

Some recent studies have shown that hydroblasting at high and ultrahigh pressure seems to be effective at dissolving and removing all the salts the water jet can reach and may be a good method for soluble salt removal.

Some recent data on the effectiveness of wet and dry methods in removing chlorides have been summarised by Appleman [43] (Table 2).

In a very recent study carried out in CENIM and INETI [47] it has been attempted to compare the chloride removal efficiency of conventional techniques (brushing and dry blasting at different grades) with hydroblasting on panel contaminated both, naturally after 3 months of exposure at Sines (Portugal) atmosphere and artificially in the salt fog cabinet after 10, 20 and 30 hours of exposure.

As can be seen in Fig. 5, blasting achieves greater efficiency than brushing. This can be seen, for instance, in the case of natural contamination, where the chloride removal rates after blasting are approximately $70 \%$ and $75 \%$ of the initial contents after thorough (DSa2) and very thorough (DSa2 $\frac{1}{2}$ ) blast cleaning, respectively. In the case of artificial contamination, the removal efficiency is also higher, near $85 \%$ for thorough blast cleaning and over $90-95 \%$ after very thorough blast cleaning. Even so, the remaining 175-200 $\mathrm{mg} \mathrm{Cl}^{-} / \mathrm{m}^{2}$, measured on both naturally and artificially contaminated surfaces after the application of very thorough dry blast cleaning, amply exceed the critical level of $100 \mathrm{mg} \mathrm{Cl} / \mathrm{m}^{2}$ often considered to be the maximum allowable value for most conventional paint systems [3].

Hydroblasting achieves the greatest efficiency, especially on artificially contaminated surfaces. In this case the removal efficiency is near $99 \%$ and the residual chloride level obtained, $20-50 \mathrm{mg} \mathrm{Cl} / / \mathrm{m}^{2}$, is a tolerable level for most paint systems. However, in the case of natural contaminated surfaces where chlorides are more difficult to remove, hydroblasting is not effective to reduce chloride levels to the allowable values for many conventional paint systems. 
Table 2. Comparison of salts removal obtained by different cleaning methods.

\begin{tabular}{|c|c|c|c|c|c|}
\hline \multicolumn{3}{|c|}{ Method } & $\begin{array}{c}\text { Remaining salts } \\
\left(\mathrm{mg} / \mathrm{m}^{2}\right)\end{array}$ & $\%$ Extracted & Reference \\
\hline \multirow{8}{*}{ Brushing } & \multirow{2}{*}{ Hand tool } & Wire brush & $1600-2880$ & $43.8 \%$ & Forsgren et al.[44] \\
\hline & & Wire brush & 152 & $9 \%$ & Allen[45] \\
\hline & \multirow{6}{*}{ Power tool } & Wire brush & $2120-2960$ & $35.4 \%$ & Forsgren et al.[44] \\
\hline & & Needle gun & 114 & $3 \%$ & Allen[45] \\
\hline & & Slight & $162-241$ & $43.5 \%$ & Trimber[46] \\
\hline & & Slight + steam & $86-129$ & $69.9 \%$ & Trimber[46] \\
\hline & & Intense & $70-139$ & $72.1 \%$ & Trimber[46] \\
\hline & & Intense + steam & $39-77$ & $84.5 \%$ & Trimber[46] \\
\hline \multirow{5}{*}{ Blasting } & \multirow{3}{*}{ Dry } & $\begin{array}{l}\text { With abrasive } \\
\text { (comercial grade) }\end{array}$ & $440-680$ & $83 \%$ & Forsgren et al.[44] \\
\hline & & $\begin{array}{l}\text { With abrasive } \\
\text { (near white metal) }\end{array}$ & 33 & $84 \%$ & Allen[45] \\
\hline & & $\begin{array}{l}\text { With abrasive } \\
\text { (white metal) }\end{array}$ & $32-34$ & $90.2 \%$ & Trimber[46] \\
\hline & \multirow[b]{2}{*}{ Wet } & With abrasive & $0-32$ & $96.2 \%$ & Forsgren et al.[44] \\
\hline & & $\begin{array}{c}\text { Ultra High Pressure } \\
\text { Waterjet }\end{array}$ & $16-18$ & $93.5 \%$ & Allen[45] \\
\hline
\end{tabular}

In the previous mentioned ECSC research project [42], an assessment of the main surface cleaning methods was also carried out. All levels of sulphate tested could be reduced to an acceptable level by using only blast cleaning. For chloride contamination, however, it appears that when extensive pitting of the steel has occurred over a significant period of time, a combination of high pressure water washing and blast cleaning struggles to bring down the contaminants to an acceptable level. Anyway, the efficiency of the surface preparation techniques depended on the features of the soluble salts distribution. The main conclusions obtained were:

(i) In case of a low soluble salts contamination, that was homogeneously distributed across the rust layer and the pits, the usual blast cleaning process successfully removed the chlorides and sulphates contamination, down to concentrations around $50-70 \mathrm{mg} / \mathrm{m}^{2}$, without any additional treatment. If the initial contamination was very low, the residual contamination after blast cleaning was almost null.

(ii) In case of an heterogeneous salts distribution produced by rain washing, featuring a very heavy contamination in the pits and a low concentration in the rust layer, blast cleaning allowed to decrease to sulphates concentration down to $100 \mathrm{mg} / \mathrm{m}^{2}$, but the combination with high pressure water cleaning was necessary to eliminate chlorides down to $200-150 \mathrm{mg} / \mathrm{m}^{2}$.

(iii) In case of a high contamination homogeneously distributed across the rust layer and the pits ( 2 months sample), blast cleaning allowed to 
eliminate the sulphates down to $50 \mathrm{mg} / \mathrm{m}^{2}$ but it had to be completed by high pressure water cleaning to successfully eliminate the chlorides down to $100 \mathrm{mg} / \mathrm{m}^{2}$.

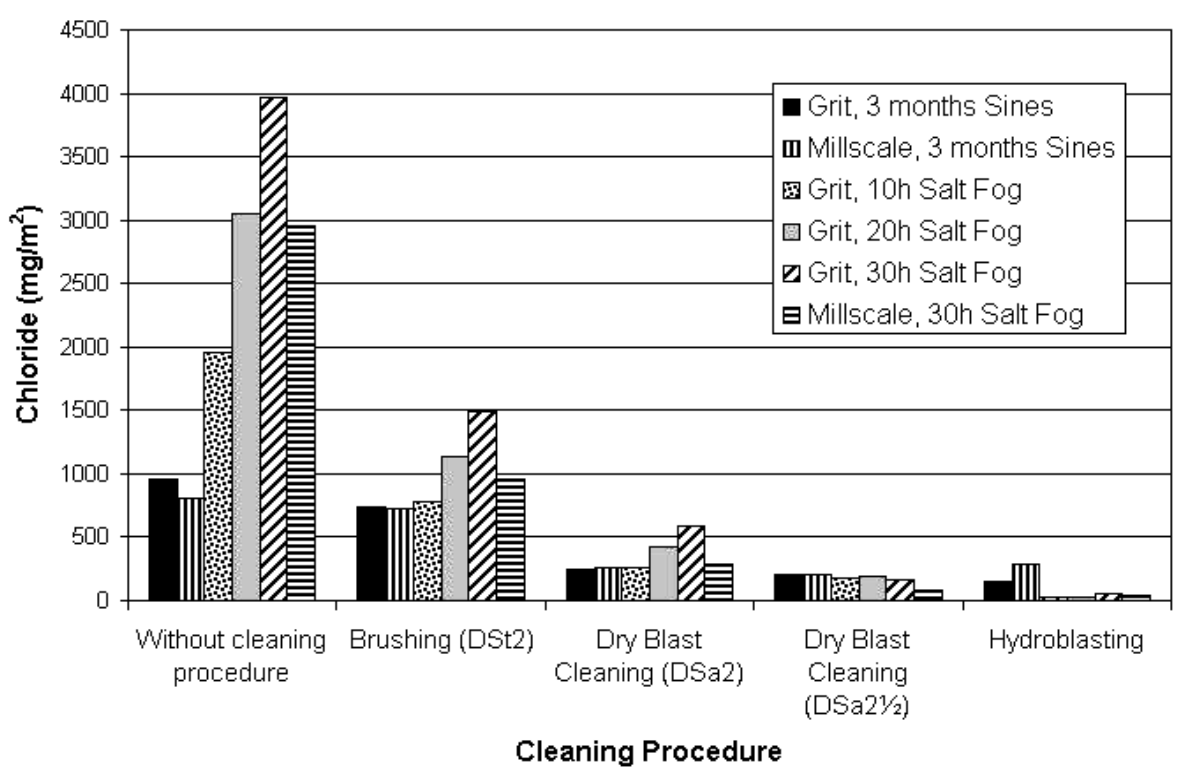

Figure 5. Chloride levels measured after different cleaning procedures.

\section{New suitable coating systems}

Coating degradation induced by the presence of soluble salts at the metal/paint interface strongly depends upon osmotic water migration through the coatings. Thus, the thickness and formulation of the coatings are critical factors for a good in service behaviour of the coating applied on a contaminated surface.

Soluble salts effects could be restrained by the use of very thick coatings (effective in preventing the entrance of water and oxygen molecules through the organic coating) or by "inertisating" the aggressive species (formation of insoluble compounds through the chemical reaction of some pigments with saline species). On this way, many studies [48-50] have shown that zinc-rich primers (ZRP) offer good anti-corrosive behaviour, and are an ecologically acceptable solution (better than the very start barium, cadmium or chromium compounds), when applied on carbon steel substrates that are rusted and contaminated with up to certain levels of chlorides and sulphates due to the formation of very insoluble compounds.

This conclusion has been confirmed in the recent ECSC project cited previously [42] where the systems based on zinc rich primers appeared to show the best resistance to the presence of soluble salts at the interface. In all the tests carried out little or no degradation was observed when the coatings were applied at the recommended thickness, even under aggressive immersion conditions, although some paint manufacturers do not recommend zinc rich systems for immersion service because it is thought that zinc salts can create intercoat adhesion problems. It may appear, therefore, that zinc-based systems are the solution 
where there is a risk of high salt contamination, at least for atmospheric exposures. The high tolerance of zinc based coatings is reflected not only in the results reported in this study but also within ISO proposed standard, where higher levels are also suggested as being appropriate.

In research carried out by de la Fuente et al. [51], the effects of some pigments such as calcium phosphate, zinc phosphate and zinc-iron phosphate, used as copigments in ZRPs were evaluated. These pigments do not present ecological limitations and could improve the anticorrosive behaviour of the ZRPs. According to the results obtained in the study, the addition of phosphate type copigments improves the behaviour of ZRPs, especially in the case of zinc phosphate, and thus makes it possible to increase critical saline contamination levels. The worst behaviour was provided by zinc-iron phosphate, while calcium phosphate showed intermediate results. With regard to co-pigment concentration, the best results were obtained at the maximum concentration tested, which was $10 \%$, especially in the case of zinc phosphate.

On the other hand some barrier coatings, such as glass flake epoxy coating system or fusion bonded epoxy coating systems have been also tested [42]. Although results are not as excellent as in the case of zinc rich paints, these systems can tolerate high levels of soluble salts for most service conditions tested.

\section{References}

1. M. Morcillo, Prog. Org. Coat. 36 (1999) 137-147.

2. J.E.O. Mayne, J. Appl. Chem. 9 (1959) 673-680.

3. B.P. Alblas, A.M. van Londen, Protect. Coat. Eur. February (1997) 18-25.

4. E.L. Koehler, Corrosion 33 (6) (1977) 209.

5. $\quad$ L.A. Van der Meer-lerk, P.M. Heertjes, J. Oil Col. Chem. Assoc. 58 (1975) 7984.

6. A. Krolikowska, "Organic and inorganic coatings for corrosion prevention, research and experiences", in: Proceedings of the EUROCORR'96, The Institute of Materials, London, 1997, p. 115.

7. W. Funke, Prog. Org. Coat. 9 (11) (1981) 29.

8. A.N. McKelvie, J. Oil. Col. Chem. Assoc. 60 (1976) 227.

9. A. Bresle, Metal Finishing, August (1976) 23.

10. C.G. Munger, "Sulphides: their effect on coatings and substrates", CORROSION/77 (NACE), Paper no. 1, Houston (1977).

11. M. Morcillo, L.S. Hernández, J. Simancas, S. Feliu Jr., S. Gimenez, J. Oil Col. Chem. Assoc. 73 (1) (1990) 24.

12. S. Frondistou-Yannas, SSPC Report no. 86-07, Pittsburgh, December 1985.

13. M. Morcillo, F.J. Rodríguez, J.M. Bastidas, Prog. Org. Coat. 31 (1997) 245-353.

14. J.M. Bastidas, M. Morcillo, F.J. Rodríguez, J. Coat. Technol. 70 (882) (1998) 61.

15. S. Flores, M. Morcillo, Surf. Coat. Int. 82 (1) (1999) 19-25.

16. K.A. Chandler, J.E. Stanners, in: Proceedings of the Second International Congress on Metallic Corrosion, New York, 1963, p. 325. 
17. D.A. Bayliss, K.A. Chandler, Steelwork Corrosion Control, Elsevier, UK, 1991, p. 28.

18. T.K. Ross, B.G. Callaghan, Corros. Sci. 6 (1966) 337.

19. H.R. Copson, Proc. ASTM 45 (1945) 554.

20. P.J. Sereda, ASTM STP 558 (1974) 7.

21. J.B. Harrison, T.C.K. Tickle, J. Oil Col. Chem. Assoc. 45 (8) (1962) 571597.

22. U.R. Evans, Nature 206 (1965) 1980.

23. M. Morcillo, S. Feliu, J. Simancas, Farbe Lack 95 (105) (1989) 726.

24. D. de la Fuente, B. Chico and M. Morcillo, Anti-Corros. Method Mat. 50 (2003) 208-216.

25. D. de la Fuente, B. Chico and M. Morcillo, J. Protect. Coat. Linings. 20 (4) (2003).

26. D. de la Fuente, B. Chico and M. Morcillo, Corros. Sci. (in press).

27. D. de la Fuente, M. Rohwerder, B. Chico y M. Morcillo, Estudio comparativo de la distribución de contaminantes salinos bajo un recubrimiento de pintura mediante el empleo de una sonda Kelvin: $8^{\circ}$ Congreso Iberoamericano de Corrosión y Protección y $5^{\circ}$ Congreso de Corrosión NACE Región Latinoamericana, Santiago de Chile, 20-24 Octubre, 2003.

28. H. Mitschke, Protect. Coat. Eur. 6 (6) (2001) 18-23.

29. SSPC-TU4: "Field Methods for Retrieval and Analysis of Soluble Salts on Substrates", SSPC, (1998).

30. S.K. Boocock, R.E.F. Weaver, B. Appleman, G.C. Soltz, "Effect of Surface Contaminants on Coating Life", SSPC, Pittsburgh, (1991).

31. S. Flores, J. Simancas, M. Morcillo, J. Protect. Coat. Linings 11 (3) (1994) 76-83.

32. K. Tator, "Evaluation of the Bresle method for detecting soluble salts on steel", personal communication, (1992).

33. S.L. Chong, Y. Yao, M. Rozario, Protect. Coat. Eur. 8 (8) (2003) 42-60.

34. E. Otero, M. Morcillo, CSIC, "Dispositivo para la extracción de sales solubles en superficies", patent application n²00301766, OEPM, (2003), Madrid.

35. D. de la Fuente, "Avances en el Conocimiento de las Sales Solubles y de su Efecto en el Comportamiento del Sistema Acero/Recubrimientos Orgánicos", Ph.D. Thesis, Universidad Autónoma de Madrid, 2004.

36. D. de la Fuente, B. Chico and M. Morcillo, Prog. Org. Coat. (in press).

37. A. Beech, "The adverse effect of soluble salt contamination on the durability of subsequently applied paint systems", M.Sc. Thesis, UK, (2002).

38. J.R. Johnson, Mater. Perform. 38 (6) (1999) 48-49.

39. D. Sonntag, Korrosion 4 (4) (1973) 3-10.

40. L. Igetoft, Proc. $2^{\text {nd }}$ World Congress-Coating Systems for Bridges, October 26-27, Missouri, MO, USA, (1982). 
41. International Standard Organization/Working Group 5, "Working draft on guidance levels of water soluble salt contamination before application of paints and related products - Part 1. Chlorides and Sulphates", (2002).

42. CORUS, CSIC, MPIE, Profilarbed, "Soluble salt contamination on blast cleaned surfaces and the effect on the durability of subsequently applied coatings", ECSC Project (2001-2004).

43. B.R. Appleman, J. Protect. Coat. Linings 19 (5) (2002) 42-47.

44. A. Forsgren, C. Appelgren, Proc. PCE 2000, Génova, 8-10 Marzo (2000).

45. B. Allen, Protect. Coat. Eur. 2 (10) (1997) 38.

46. K.A. Trimber, Proc. 7th SSPC Technical Symposium, SSPC Publication 8803 (1988) 56-67.

47. D. de la Fuente, C. Brites, B. Chico, D. Santos, M. Morcillo and E. Almeida, "Assessment of the soluble salt removal efficiency of different steel surface preparation methods", EUROCORR 2005, 5-9 September 2005, Lisbon (Portugal) (accepted paper).

48. M. Morcillo, S. Feliu, J.C. Galván, J.M. Bastidas, J. Oil Col. Chem. Assoc. 71 (1) (1988) 11-17.

49. M. Morcillo, J. Simancas, J. Protect. Coat. Linings 14 (9) (1997).

50. M. Morcillo, J. Simancas, Proc. PCE'97, Paper no. 12, The Hague, March (1997).

51. D. de la Fuente, B. Chico and M. Morcillo, Rev. Metal. Madrid, Vol. Extr. (2003) 129-136. 